\title{
ELECTRONIC SYSTEM FOR TESTING TENSILE STRENGTH OF FOUNDRY SAND
}

\author{
Mohini M. Mane' ${ }^{1}$ U. L. Bombale ${ }^{2}$ \\ ${ }^{1}$ Mtech Student, Electronics Engineering, Department of Technology, Shivaji University, Maharashtra, India \\ ${ }^{2}$ Associate Professor, Electronics Engineering, Department of Technology, Shivaji University, Maharashtra, India
}

\begin{abstract}
Foundry shop is an important section in industries. In foundry manufacturing of major pieces is done, which supplies to another industries such as automotive, naval, aeronautic, weapon and agricultural industries. Many of these pieces play key roles in final product as these are used in automotive engine, aero plane components or wind energy castings. Sand is the principal moulding material in the foundry as it is using for all types of castings. This machine designs an idea of testing tensile strength of sand which is using for castings in foundries with the help of load cell. This system defines the sand whether it is good or bad for castings. We cannot check tensile strength of each grain of sand so; we form brick of that sand and then check tensile streng th of that sand brick. Sand brick is placed in between load cell and DC motor. DC motor continuously applies force on that brick till it breaks and at other side simultaneously load cell converts that force into electrical signal and analog -to-digital converter converts that into digital and it displays on LCD. Force at which point brick breaks motor automatically stops that is the maximum tensile strength of that sand.
\end{abstract}

Keywords: Casting, Load Cell, Moulding, Sand Brick, Tensile Strength

\section{INTRODUCTION}

Tensile strength is an important concept in engineering, especially in the fields of material science, mechanical engineering and structural engineering. Tensile strength testing is commonly used to determine the maximum stress of a material that can endure while being stretched or pulled before breaking. In foundry special type of sand is used for making mould. It is clean, uniformly sized, high-quality silica sand that is bounded to form moulds for ferrous (iron and steel) and non-ferrous (copper, aluminium, brass) metals. In that mould cavity the molten metal enters and sand develops several strength zones. As heat transfer theorem, heat transfers from metal to outward direction through sand. As sand has porous, refractory nature and chemical resistivity. Due to this change in the magnitude of temperature observed in mould have significant effect on sand strength.

Throughout the pouring process, sand at the mould metal interface is dramatically heated. The water inside this hot layer is vaporized and migrates between sand grains to cooler region. The thermal expansion of silica sand in the hot zone and the weakness of the wet layer can cause rupture between the two layers that is breaks the mould. So it effects on pattern of metal which we want to make. For that reason initially we want to check tensile strength of each type of sand which will be using for further processing in foundry and select which sand will stand for high temperature in casting that is which is better for further process in foundry.

\section{BACKGROUND AND RELATED WORK}

The manufacturing process in foundry is carried out in the same manner as it was many years ago.

In paper [1], steps of foundry process and mechanical properties are mentioned. In paper [2,3], effects of heat on the behaviour of sodium and calcium betonies in bonding foundry sands were studied.

In paper [4], metal industries use which types of foundry sand is mentioned. Sand which is uniform sized, high quality silica sand that is bound to form a mould for casting of ferrous and non-ferrous metal. Finer sand than normal sand is used in metal casting process.

Because of rapid temperature rise of mould/metal interface in casting process modifications the physical properties of moulding sand .The dramatic increase in temperature affects the bonding strength of clays.

In paper [5], several defects appear in castings are mentioned when the production process is already finished. One of the most difficult defects to detect is the micrshrinkag: tiny porosities that appear inside the casting. Another important aspect that foundries have to control is the attributes that measure the faculty of the casting to withstand several loads and tensions, also called [6] mechanical properties.

In paper [7], the most widely techniques that allow us to analyse castings in order to detect the microshrinkages are Xrays and ultrasonic emissions. Although these methods are not destructive, are ex-post methods, unfortunately, they 
require suitable devices, specialised staff and quite a long time to analyse all the parts.

In paper [8], when the casting is finished and is placed in a more complex system, it will be subject to several forces (loads). Therefore, it is important to recognise how mechanical properties influence iron castings.

In paper [9], specifically, the most important mechanical properties of foundry materials are mentioned.

In paper [10], currently, there are several standard procedures for measuring the performance of the materials regarding the mechanical properties; unfortunately, the only way is employing destructive inspections.

In paper [11], methods of applying loads are mentioned. Loads are generally applied either mechanically with screw drives or hydraulically with pressurized oil .Microcontroller based $\mathrm{dc}$ motor controller is mentioned [12]. Load cell interfacing to microcontroller is mentioned $[13,14]$.

\section{PROPOSED SYSTEM}

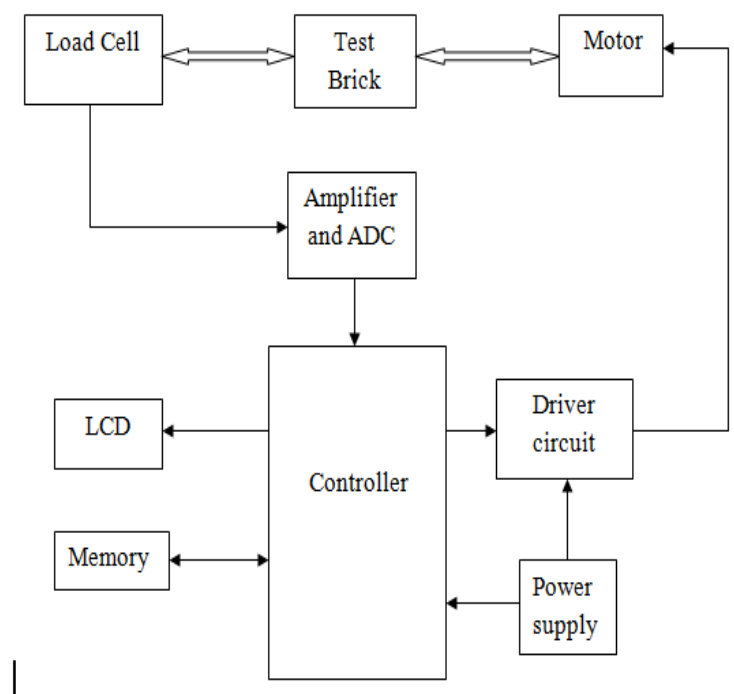

Fig -1: Block diagram of proposed system

(Figure1) shows the block diagram of proposed system. Test brick which is formed by sand which we want to test is placed between load cell and DC motor. We need to make specific shaped brick of testing sand, as cannot check tensile strength of each sand grain/particle. Driver circuit contains ULN2803 relay driver that drives relay. PIC microcontroller is mounted for controlling of whole system. INA126 IC is instrumentation amplifier is using for amplifying differential input signal from load cell and gives single ended output to ADC in PIC microcontroller for converting it to digital form. That ADC output gives to LCD for displaying output.

\section{HARDWARE IMPLEMENTATION}

\subsection{Circuit Design of Proposed System}

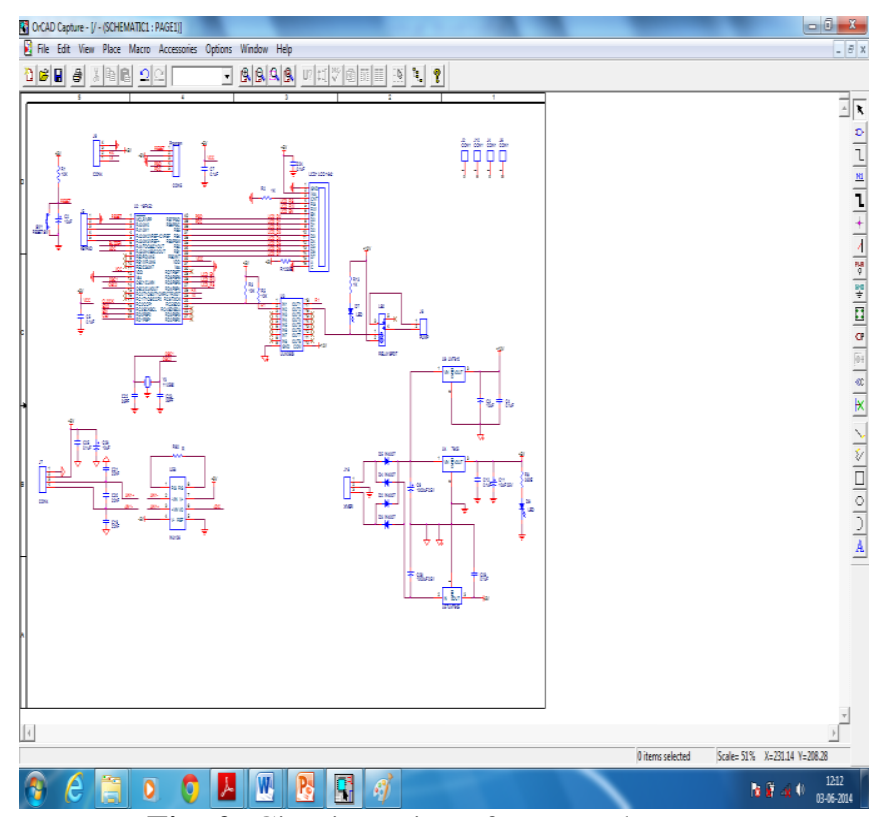

Fig -2: Circuit Design of proposed system

\subsection{Hardware Required for Proposed System}

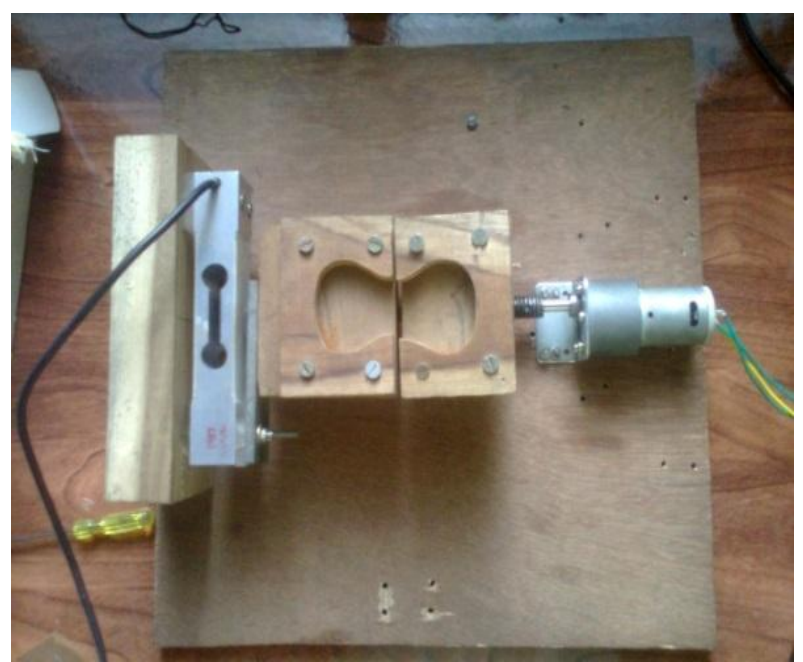

Fig -3: Hardware required for the proposed system

We are making tensile strength testing machine model using load cell shown in (figure3). Circuit design of proposed system shown in (figure2). Continues force will apply on brick with the help of DC motor. That applying force will directly converted to equivalent differential electrical signal through load cell which is based on a strain-gaged beam with a mounted Wheatstone bridge.

That differential electrical signal given to INA126 amplifier, it amplifies signal and gives single ended output to ADC of microcontroller for converting it to digital form. These continue digital readings stored into memory, perform computation and displays on LCD. The point at which test brick breaks is tensile strength of that sand. 


\section{RESULTS}

Motor based test model hardware which continuously applying forces with the help of dc motor shown (figure4)

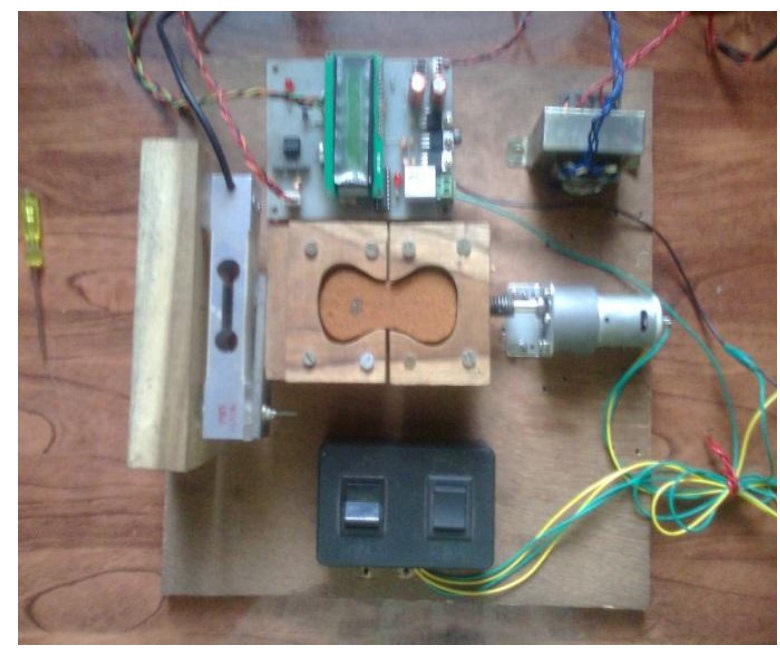

Fig -4: Proposed system before the test

As continuously applies the force on test brick with the help of DC motor, resistance of tensile gauges is increases in load cell and compression gauges decreases, so bridge becomes unbalanced and differential output voltage proportional to applied force is produced across load cell output.

That converted to single ended output with the help of INA126 instrumentation amplifier and gives to ADC of microcontroller it converts into digital form and LCD displays that digital output is the tensile strength of sand shown (figure5).

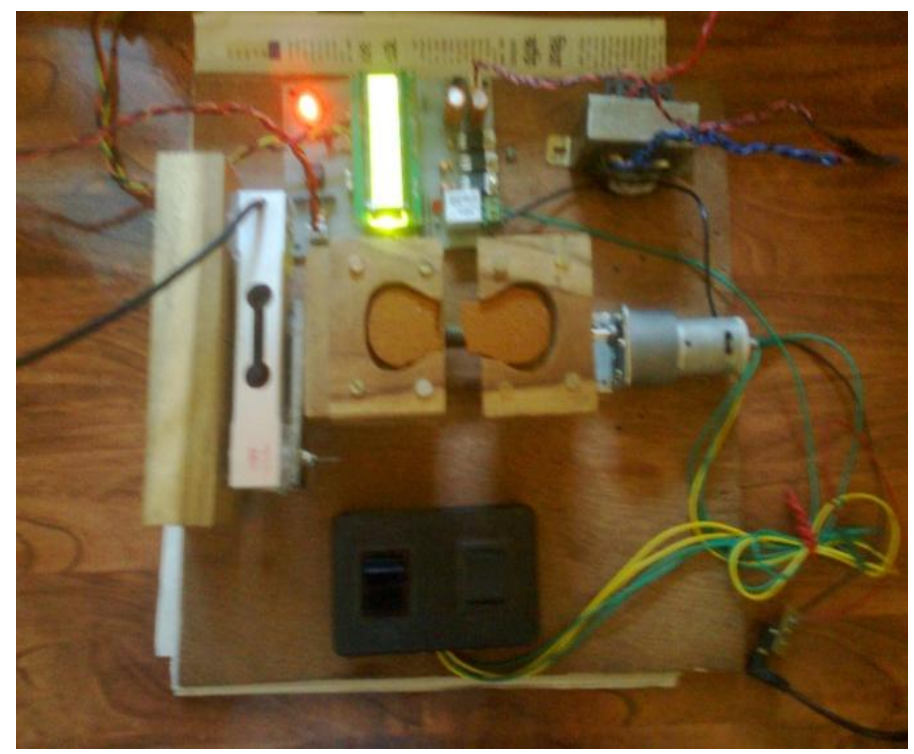

Fig -5: Proposed system after the test

\section{CONCLUSIONS}

This paper represents accurate testing of tensile strength of foundry sand. In this, pic microcontroller based testing model test the sand accurately with the help load cell. DC motor is used for applying continues force on test specimen. And that applying force converts to equivalent differential electric output signals through load cell which is based on a straingaged beam with a mounted Wheatstone bridge. This differential electrical output signals is amplified by instrumentation amplifier INA126 and it gives single ended output to controller. Controlling of DC motor is done by pic microcontroller. As test specimen brakes motor offs automatically and direct digital reading displays on LCD by analog-to-digital converter in microcontroller.

This technique does not require specialised staff and long time to analyse the materials. This system is suitable in ferrous and non-ferrous metal castings industries.

\section{ACKNOWLEDGEMENTS}

The author thankfully acknowledge to respected guide Dr. U. L. Bombale, Co-ordinator Mr. S. B. Chavan, Lab Asst., Director Mr.Sahu Sir, Department of Technology, Shivaji University, Kolhapur. Some Industrialists who helped me for completion of my project. From Paranjape Auto Cast Pvt. Ltd. Shirval, Royal Industries, Mr.Satish from Raysons Industries, Shiroli MIDC, Kolhapur.

\section{REFERENCES}

[1] J. Nieves, I. Santos, Y. K. Penya, S. Rojas, M. Salazar, and P. G. Bringas, "Mechanical properties prediction in high-precision foundry production." in Proceedings de la $7 \nmid$ IEEE International Conference on Industrial Informatics (INDIN 09), 2009, pp. 3136.

[2] Nuhu A. Ademoh, "Evaluation of the tensile strength of foundry cores made with hybridized binder composed of Neem oil and Nigerian gum Arabic" International Journal of the Physical Sciences, May 2010, ISSN 1992 - 1950 (C) 2010

[3] GEORGE J. VINGAS and ARTHUR H. ZRIMSEKJ, "THERMAL STABILITY OF BENTONITES IN FOUNDRY MOLDING SAND"

[4] Pathariya Saraswati C, Rana Jaykrushna K,“ Application of Waste Foundry Sand for Evolution of Low-Cost Concrete" International Journal of Engineering Trends and Technology (IJETT) Volume 4 Issue 10 - Oct 2013

[5] R. Siclari, T. Margaria, E. Berthelet, and J. Fourman Microshrinkage in ductile ironmechanism and solution In Proceedings of the Keith Millis Symposium on Ductile Cast Iron, 2003

[6] R. Gonzaga-Cinco and J. Fern'andez-Carrasquilla "Mechanical properties dependency on chemical composition of spheroidal graphite cast iron" Revista de Metalurgia, March-April 2006.

[7] Igor Santos, Javier Nieves, Pablo G. Bringas and Yoseba K. Penya "MACHINE-LEARNING-BASED DEFECT PREDICTION IN HIGH-PRECISION FOUNDRY PRODUCTION" ISBN: 978-1-61728104-4, 2009 Nova Science Publishers.

[8] R. Gonzaga-Cinco and J. Fern'andez-Carrasquilla, "Mecanical properties dependency on chemical 
composition of spheroidal graphite cast iron," Revista de Metalurgia, vol. 42, 2006

[9] C. Lung and N. March, Mechanical Properties of Metals: Atomistic and Fractal Continuum Approaches. World Scientific Pub Co Inc, Julio1992.

[10] Scott Strobal, Vice President of Technology, Simpson Technologies Corporation Aurora, Illinois, USA. "Improving Sand Control with Wet Tensile Testing."

[11] Introduction to Tensile Testing, 2004 ASM International.

[12] Suroor Moaid Dawood, Dr.Rabee' Hashim Thejeel "PIC 16F877A Microcontroller Based Multiple DC Motors Controller" Asian Transactions on Engineering (ATE ISSN: 2221-4267) Volume 03 Issue 02, May 2013

[13] J. H. Correia, J. G. Rocha, C. Couto, "Smart Load Cells: an Industrial Application"

[14] High Resolution Digital Weigh-Scale Desig Using Z8 Encore!® Microcontrollers 